Canadian Journal of Soil Science Revue canadienne de la science du sol

\title{
Kinetics and Thermodynamics of Phosphorus Sorption on Goethites: Effects of Biochar Application
}

\begin{tabular}{|r|l|}
\hline Journal: & Canadian Journal of Soil Science \\
\hline Manuscript ID & CJSS-2017-0094.R2 \\
\hline Danuscript Type: & Article \\
\hline Complete List of Authors: & $\begin{array}{l}\text { Pereira, Fernanda; University of Manitoba } \\
\text { Amarakoon, Inoka; University of Manitoba } \\
\text { Zvomuya, Francis; University of Manitoba, Soil Science } \\
\text { Jeke, Nicholson; University of Manitoba }\end{array}$ \\
\hline Keywords: & biochar, phosphorus sorption, goethite, thermodynamics, sorption kinetics \\
\hline & \multicolumn{2}{|l}{} \\
\hline
\end{tabular}




\section{Kinetics and Thermodynamics of Phosphorus Sorption on Goethites: Effects of Biochar Application}

Fernanda G. Pereira, Inoka D. Amarakoon, Francis Zvomuya*, and Nicholson N. Jeke

Department of Soil Science, 362 Ellis Building, University of Manitoba, Winnipeg, Manitoba, Canada R3T 2N2

* Corresponding author (francis.zvomuya@umanitoba.ca)

Abbreviations: Al, aluminum; BET (batch equilibration technique); Fe, iron; P, phosphorus. 


\begin{abstract}
Bioavailability of phosphorus $(\mathrm{P})$ in soils is controlled by, inter alia, the presence of Fe and Al oxides, which readily bind with P. Biochar has been suggested for minimizing P sorption to oxides and, therefore, improving $\mathrm{P}$ availability to plants. However, the kinetics and temperature dependence of biochar influence on P sorption are poorly understood. The objective of this study was, therefore, to determine the kinetics and thermodynamics of $\mathrm{P}$ sorption by goethite as affected by biochar application at 0 and $40 \mathrm{~g} \mathrm{~kg}^{-1}$ oxide. Batch equilibration tests were run at 15 , 25 , and $35^{\circ} \mathrm{C}$, and solution $\mathrm{P}$ concentrations were measured $0.5,1,3,6,9,12$, and $24 \mathrm{~h}$ after the start of incubation. Sorption of P by the oxides followed pseudo-first-order kinetics. Biochar application enhanced cumulative P sorption by both oxides, and the increase was greater for Algoethite. Phosphorus sorption increased as temperature increased from $15^{\circ} \mathrm{C}$ to $25^{\circ} \mathrm{C}$ but declined at $35^{\circ} \mathrm{C}$. Phosphorus sorption on biochar-amended oxides was associated with low activation energy $\left(E_{a}\right)$ values, indicating that the sorbed $\mathrm{P}$ in soils containing goethite and Algoethite could still be plant available. This information will contribute towards a better understanding of processes affecting biochar effects on $\mathrm{P}$ fate in soils.
\end{abstract}


The management of $\mathrm{P}$ to maximize crop yields while minimizing environmental contamination is critical (Cordell et al., 2011). It is well-known that the bioavailability of $\mathrm{P}$ in soils is controlled by, inter alia, the presence of iron (Fe) and aluminum (Al) oxides, which are found in almost all soils but are dominant in highly-weathered soils (Qafoku et al., 2004). Goethite $(\alpha-\mathrm{FeOOH})$ is the main oxide in these soils, but the Fe in the goethite structure can be substituted by a large number of cations, mostly $\mathrm{Al}$ due to its abundance in rocks and soils, and its mobilization with Fe during the weathering process (Cornell and Schwertmann, 2003; Qafoku et al., 2004). Phosphorous sorption onto goethite occurs due to the crystal morphology and high specific surface area of these minerals (Ruan and Gilkes, 1996; Cornell and Schwertmann, 2003; Hua et al., 2012). Factors influencing the rate of P sorption on goethites are pH (Barrow, 1984; Antelo et al., 2005; Persson et al., 2012), solution ion composition (Antelo et al., 2005; Weng et al., 2012), temperature, time of contact (Barrow, 1983), and organic matter content ( Sibanda and Young, 1986; Weng et al., 2012; Fu et al., 2013).

Many studies have examined ways of improving soil fertility by minimizing P sorption by oxides in soils, with one of the promising approaches being the use of biochar (Daza-Torres et al., 2008; Duku et al., 2011). Biochar is a carbon-rich material produced from the pyrolysis of organic materials (Schoumans et al., 2015). The practice of adding biochar to soil originated approximately 2500 years ago in Native American settlements of the Amazon region, Brazil (Atkinson et al., 2010; Duku et al., 2011). Amazon Basin soils are highly weathered and consequently have low fertility (Wambeke, 1992). By adding a mixture of charcoal and nutrientrich materials to infertile Amazonian soils over many years, a dark soil (locally known as Terra Preta de Indio) was formed (Atkinson et al., 2010; Kookana et al., 2011). The fertility, organic matter content, and cation exchange capacity (CEC) of these soils are significantly higher than 
those of adjacent soils (Oxisols) (Liang et al., 2006) due to the active, porous surface properties (Yao et al., 2010) and chemical make-up of the surface groups of biochar (Spokas et al., 2012).

Biochar has been shown to increase P availability and plant productivity (Lehmann et al., 2003; Duku et al., 2011). Cui et al. (2011) reported a 30-40\% reduction in $\mathrm{P}$ sorption by ferrihydrite, hence increased $\mathrm{P}$ availability, following the addition of rice straw-derived biochar. Similarly, Jiang et al. (2015) reported a decrease in P sorption in variable-charge soils amended with crop straw-derived biochar. In contrast, Novak et al. (2009) observed a decrease in leachate $\mathrm{P}$ concentration when pecan shell biochar was applied to a loamy sand, suggesting greater sorption with the addition of the biochar. Similarly, wheat straw biochar increased P sorption in an acidic inceptisol (Xu et al., 2014). Parvage et al. (2013) reported that wheat residue biochar can act as a $\mathrm{P}$ sink when applied at 20 to $40 \mathrm{~g} \mathrm{~kg}^{-1}$ soil, whereas at biochar rates of $\leq 20 \mathrm{~g} \mathrm{~kg}^{-1}$, the biochar had no significant effect. However, other studies found that biochar had no significant effect on P sorption (Soinne et al., 2014) or leachability of P (Iqbal et al., 2015) in amended soils.

Temperature can affect the rate of $\mathrm{P}$ sorption and the strength of $\mathrm{P}$ bonding in the soil. High soil temperatures may favor fast P sorption (Gardener and Johnes 1973; Chien et al., 1982) and strong $\mathrm{P}$ bonding via chemisorption, which requires a high activation energy (Spark 1989; Weber et al., 1991), increasing $\mathrm{P}$ fixation by oxides in soil and, therefore, making $\mathrm{P}$ less available to crops (Barrow, 1979). On the other hand, low soil temperatures may limit the plant availability of P via decreased desorption (Gardener and Johnes 1973). Thus, an understanding of how temperature affects $\mathrm{P}$ sorption in the presence of biochar provides crucial information for effective management of $\mathrm{P}$ in soil. This is especially true for Canadian soils where temperature 
varies greatly during the growing season, with implications on $\mathrm{P}$ availability (Manitoba Soil Fertility Guide, 2007).

To our knowledge, the effects of biochar on the kinetics and temperature dependence of $\mathrm{P}$ sorption by goethite - an important constituent of soils - have not been investigated. Therefore, the objective of this experiment was to determine the kinetics and thermodynamics of P sorption by goethite as affected by biochar application.

\section{MATERIALS AND METHODS Preparation of Oxides and Biochar}

Goethite $(\alpha-\mathrm{FeOOH})$ was synthesized following the procedure of Schwertmann and Cornell (2003). Briefly, $180 \mathrm{~mL}$ of $5 \mathrm{M} \mathrm{KOH}$ were rapidly stirred into $100 \mathrm{~mL}$ of a $1 \mathrm{M}$ $\mathrm{Fe}\left(\mathrm{NO}_{3}\right)_{3} \cdot 9 \mathrm{H}_{2} \mathrm{O}$ solution in a 2-L polyethylene flask. After stirring, the suspension was immediately diluted to $2 \mathrm{~L}$ with reverse osmosis (RO) water and left in a $70^{\circ} \mathrm{C}$ oven for $60 \mathrm{~h}$. The resulting suspension was centrifuged, rinsed with $\mathrm{RO}$ water, and then dried in an oven at $60^{\circ} \mathrm{C}$ for $24 \mathrm{~h}$.

Aluminum-substituted goethite was synthesized by mixing $1 \mathrm{M} \mathrm{Fe}\left(\mathrm{NO}_{3}\right)_{3}$ and $0.5 \mathrm{M} \mathrm{AlCl}_{3}$ solutions in a polyethylene flask (Schultze and Schwertmann, 1984; Torrent et al., 1992) and then rapidly stirring in $0.3 \mathrm{M} \mathrm{KOH}$. The solutions were subsequently stored in an oven at $70^{\circ} \mathrm{C}$ for $14 \mathrm{~d}$. The resulting suspension was centrifuged, washed, and dried for $24 \mathrm{~h}$.

Biochar was obtained from Diacarbon Energy, Inc. (Burnaby, BC) and produced from the pyrolysis of wood chips at approximately $500^{\circ} \mathrm{C}$. The chemical composition of the biochar used in this experiment was obtained from manufacture and is listed in Table 1. 


\section{Experimental Design}

The experiment was laid out as a completely randomized design with a $2 \times 2 \times 3$ factorial treatment structure. The factors were an oxide (Goethite and Al-substituted goethite), biochar rate $\left(0\right.$ and $40 \mathrm{~g} \mathrm{~kg}^{-1}$ oxide), and reaction temperature $\left(15,25\right.$, and $\left.35^{\circ} \mathrm{C}\right)$. Reaction times were $0.5,1,3,6,9,12$, and $24 \mathrm{~h}$. All treatments were replicated three times. A separate set of triplicate blanks containing the background solution were included to quantify the release of $\mathrm{P}$ from biochar as a quality control measure.

\section{X-Ray Diffraction (XRD) Analysis and Scanning Electron Microscopy with X- ray Microanalysis (SEM-EDS) of Goethite and Al-substituted Goethite}

X-ray diffraction patterns of the samples were analyzed with a Siemens D5000 powder diffractometer $(\mathrm{Cu}-\mathrm{KQ}$ radiation, $\lambda=1.54178 \AA ⿱ \mathrm{~A})$ ) equipped with a scintillation detector and a graphite monochromator, and operated at a tube voltage of $40 \mathrm{kV}$ and a tube current of $40 \mathrm{~mA}$. Step scan data were collected from $3-65^{\circ} 2 \theta$ using a step-width of $0.02^{\circ} 2 \theta$ and a dwell time of 1 $\mathrm{s}$ step $^{-1}$. Divergence and anti-scatter slits were both set to $1^{\circ}$. The datasets were subsequently processed using the Jade v9.5 software package and the Powder Diffraction File (PDF-4+ 2012) database.

The technique of X-ray microanalysis with energy dispersive spectroscopy (EDS) was used to measure $\mathrm{Al}$ substitution in the goethite structure and to detect impurities (Table 2). This technique allows the determination of amounts up to $1-2 \%$ of the elements present per volume micrometer of the samples (Dedavid et al., 2007). Goethite and Al-substituted goethite samples were placed on aluminum specimen holder stubs with double-sided carbon tape holding the specimens in place. The samples then received a carbon bath. Samples were observed in a 
Scanning Electron Microscope (SEM) LEO EVO 40 PVX and analyzed by a microanalysis Xray system (Bruker, Madison, WI, USA). Several images were generated for each sample at 20 $\mathrm{kV}$ and a working distance of 5.5 to $6.5 \mathrm{~mm}$. The X-ray microanalysis used the energy of $10 \mathrm{kV}$, accelerating potential of $15.0 \mathrm{kV}$, and a current ranging from $2.48 \times 10^{-9}$ to $2.54 \times 10^{-9} \mathrm{~A}$.

X-ray diffraction patterns for the synthesized goethite and Al-goethite show that these oxides have low crystallinity (Fig. 1). The XRD for goethite showed peaks at d values of 4.19, $3.37,2.69,2.58,2.45,2.25,2.19 \AA$, indexed, respectively, to the (110), (120), (130), (021), (111), (121), and (140) planes of pure goethite (JCPDS Card No. 17-0536). For Al-goethite, the $\mathrm{d}$ values were $4.18,3.37,2.68,2.57,2.44,2.24$, and $2.18 \AA$, with typical peaks of (110), (120), (130), (021), (111), (121), and (140), respectively. Overall, the d-values for these characteristic peaks were smaller for Al-goethite as expected since $\mathrm{Al}^{3+}(0.53 \AA)$ has a slightly smaller radius than $\mathrm{Fe}^{3+}(0.65 \AA)$ (Schulze, 1984). The substitution of Al for Fe in the goethite structure will, therefore, cause a decrease in the average size of the unit cell, related to the degree of $\mathrm{Al}$ substitution and can be indicated by Al-goethite XRD lines shifting towards smaller d spacings. Potassium (from the background $\mathrm{KOH}$ solution) and $\mathrm{Al}$ were found in the Fe-goethite as impurities. In contrast, only Fe and Al were detected in the Al-substituted goethite. The synthetic Fe-goethite mainly contained $\mathrm{Fe}(72 \%)$. The results of a semi-quantitative analysis indicated goethite contained $0.69 \% \mathrm{Al}$ while Al-goethite contained $2.96 \% \mathrm{Al}$, confirming greater $\mathrm{Al}$ substitution in Al-goethite as expected.

\section{Batch Equilibration Study}

A batch equilibration technique was used to investigate the kinetics and thermodynamics of $\mathrm{P}$ sorption by goethite and Al-substituted goethite in the presence of biochar. The sample 
treatments were prepared by adding $0.1 \mathrm{~g}$ of each oxide (goethite or Al-substituted goethite) into 125-mL Erlenmeyer flasks containing $7 \mathrm{mg} \mathrm{P} \mathrm{L}^{-1}$ in a $100 \mathrm{~mL}$ solution of $\mathrm{KH}_{2} \mathrm{PO}_{4}$ in $0.01 \mathrm{M}$ $\mathrm{KCl}$. Biochar was mixed with each oxide (goethite and Al-goethite) at a rate of $40 \mathrm{~g} \mathrm{~kg}^{-1}$ for treatments receiving biochar. Control treatments received either oxide but no biochar. The experiment was conducted at three temperatures $\left(15,25\right.$, and $\left.35^{\circ} \mathrm{C}\right)$ and seven incubation times $(0.5,1,3,6,9,12$, and 24 hours). Additionally, a set of blanks consisting of the background solution only were included as a quality control measure to account for the release of $\mathrm{P}$ from biochar. All treatments were replicated three times, resulting in 378 experimental units. The $\mathrm{pH}$ of the resulting suspension was immediately adjusted to $5.5 \pm 0.5$ by adding $\mathrm{HNO}_{3}$ or $\mathrm{KOH}$ solutions. The starting time of the sorption reaction was set just after $\mathrm{pH}$ adjustment.

All treatments were allowed to equilibrate by shaking at $200 \mathrm{rpm}$ in a C24KC Refrigerated Incubator shaker for $0.5,1,3,6,9,12$, and $24 \mathrm{~h}$ at three reaction temperatures $(15,25$, and $35^{\circ} \mathrm{C}$ ). After each reaction time, $10-\mathrm{mL}$ aliquots were taken and centrifuged for $30 \mathrm{~min}$ at 10,000 rpm in an IEC CL31R multispeed centrifuge (Thermo Electron Corp., Waltham, MA, USA). The reaction temperatures were maintained during centrifugation. Immediately after centrifuging, the samples were passed through $0.45 \mu \mathrm{m}$ cellulose Nitrate membrane filters by vacuum filtration. Phosphorus concentrations in the filtrates were measured using a Vista inductively coupled plasma atomic emission spectrometer (Varian Inc., Palo Alto, CA, USA). Phosphorus sorption was calculated as the difference between the initial solution $\mathrm{P}$ concentration and the solution $\mathrm{P}$ concentration after reaction. Solution $\mathrm{pH}$ was measured with a Fisher Accumet AB $15 \mathrm{pH}$ meter (Fisher Scientific, Hampton, NH, USA). 


\section{Statistical Analysis}

A comparison, using PROC NLIN in SAS 9.4 (SAS Institute, 2013), of pseudo-first-order and pseudo-second-order kinetic models, which are commonly used in studies of $\mathrm{P}$ sorption by Fe oxides (Ainsworth and Sumner, 1985; Cui et al., 2011), indicated that the pseudo-first order model provided a better fit to our data. The pseudo-first order model is as follows:

$$
q_{t}=q_{e}\left(1-e^{-k t}\right)
$$

where $q_{t}$ is the sorption capacity $\left(\mathrm{mg} \mathrm{g}^{-1}\right)$ at time $t(\mathrm{~h}), q_{e}$ is the sorption capacity at equilibrium $\left(\mathrm{mg} \mathrm{g}^{-1}\right)$, and $k$ is the pseudo-first order rate constant $\left(\mathrm{h}^{-1}\right)$. Treatment differences in parameters were compared using $95 \%$ confidence intervals of the parameters.

The activation energy of $\mathrm{P}$ sorption $\left(E_{a}, \mathrm{~kJ} \mathrm{~mol}^{-1}\right)$ was estimated by the Arrhenius equation using PROC NLIN:

$$
k=A_{e}^{(-E a / R T)}
$$

where $A$ is the frequency or pre-exponential factor $\left(\mathrm{h}^{-1}\right), R$ is the gas constant $\left(8.314 \mathrm{~J} \mathrm{~mol}^{-1} \mathrm{~K}^{-1}\right)$, and $T$ is the absolute temperature $(\mathrm{K})$.

An ANOVA was performed on cumulative $\mathrm{P}$ sorption data at $24 \mathrm{~h}$ (which were normally distributed) using PROC MIXED in SAS 9.4, and the means were compared using the TukeyKramer mean comparison procedure. 


\section{RESULTS AND DISCUSSION}

\section{Biochar Characterization}

Initial chemical properties (measured by a commercial laboratory) of the biochar used in this experiment are presented in Table 1. The concentrations of $\mathrm{P}, \mathrm{Ca}$, and $\mathrm{Mg}$ are similar to those reported for wood biochars in other studies (Atkinson et al., 2010; Zhao et al., 2013). Sorption results from the set of blanks consisting of the background solution with biochar but no oxides showed that the biochar P remained sorbed (i.e., did not go into solution) after $24 \mathrm{~h}$ of reaction (data not presented).

\section{Phosphorus Sorption Kinetics}

The sorption of $\mathrm{P}$ by Fe oxides was adequately described by the pseudo-first-order kinetic model. Phosphate was rapidly sorbed by the oxides within $2 \mathrm{~h}$; this was followed by a slower and constant sorption pattern (Fig. 2). This sorption pattern has been reported in other studies (Luengo et al., 2007; Jaisi et al., 2010; Cui et al., 2011). Strauss et al. (1997) proposed that P is initially sorbed onto charged external surfaces of goethite during the period of fast P sorption and then diffuses into the particle, where slow and constant sorption takes place. Phosphorus precipitation on goethite was also proposed as a mechanism during the slow $\mathrm{P}$ sorption phase (Martin et al., 1988). As temperature increased, rate constants $(k)$ increased from 3.8 to $7.7 \mathrm{~h}^{-1}$ in the unamended goethite and from $2.8 \mathrm{~h}^{-1}$ to $5.1 \mathrm{~h}^{-1}$ in the biochar-amended goethite, indicating that $\mathrm{P}$ sorption by goethite is favored by the increasing temperature and thus is endothermic. The increase in the sorption rate constant and the sorption capacity with increasing temperature has previously been reported for iron oxides (Mezenner and Bensmaili, 2009; Luengo et al., 2007). 
For Al- substituted goethite, in contrast, $k$ decreased with increasing temperature from $1.8 \mathrm{~h}^{-1}$ to $0.8 \mathrm{~h}^{-1}$ in the absence of biochar and from 1.2 to $0.7 \mathrm{~h}^{-1}$ when biochar was added, indicating an exothermic reaction. However, $k$ did not differ significantly among temperatures, between oxide types and between the two biochar rates.

\section{Activation Energy (Ea)}

The $E_{a}$ for sorption of $\mathrm{P}$ by goethite was positive $\left(1.53 \mathrm{~kJ} \mathrm{~mol}^{-1}\right.$ with biochar added and $11.3 \mathrm{~kJ} \mathrm{~mol}^{-1}$ without biochar), which is consistent with the observed increase in the first order rate constant $(k)$ as the temperature increased from 15 to $35^{\circ} \mathrm{C}$. By contrast, $E_{a}$ for $\mathrm{P}$ sorption by Al-goethite was negative (-9.59 $\mathrm{kJ} \mathrm{mol}^{-1}$ with biochar added and $-29.3 \mathrm{~kJ} \mathrm{~mol}^{-1}$ without biochar), which is consistent with the reduction in $k$ as the temperature increased to $35^{\circ} \mathrm{C}$. Averaged across temperatures and regardless of oxide type, $E_{a}$ did not differ significantly between the 0 and the $40 \mathrm{~g} \mathrm{~kg}^{-1}$ biochar rates. The low magnitude of the $E_{a}\left(< \pm 42 \mathrm{~kJ} \mathrm{~mol}^{-1}\right)$ (Sparks 1989) obtained in this experiment is consistent with those reported in other studies for $\mathrm{P}$ sorption on $\mathrm{Fe}$ and $\mathrm{Al}$ oxides and hydroxides (Kuo and Lotse, 1973; Liu and Huang, 2000; Luengo et al., 2007). Low activation energies may indicate that $\mathrm{P}$ sorption is a diffusion-controlled process, occurring by means of physical sorption rather than chemisorption (Sparks 1989).

\section{Cumulative Phosphorus Sorption}

Biochar rate effect on cumulative $\mathrm{P}$ sorption varied with oxide type and temperature, as indicated by the significant biochar $\times$ oxide $(P=0.02)$ (Fig.3) and biochar $\times$ temperature $(P=$ $<0.001$ ) (Fig.4) interactions (Table 3). The addition of biochar significantly increased the amount of $\mathrm{P}$ adsorbed by both oxides after $24 \mathrm{~h}$ of reaction. In the presence of biochar, Al-goethite adsorbed significantly more $\mathrm{P}$ than goethite. The observed increase in $\mathrm{P}$ sorption with biochar 
addition is consistent with results from previous studies, which also showed greater sorption with the incorporation of biochar (Novak et al., 2009; Parvage et al., 2013; Xu et al., 2014). The sorption capacity of biochar arises from its high specific surface area and microporosity (Kookana et al., 2011; Zhao et al., 2017). Also, the positive charge of biochar may provide additional $\mathrm{P}$ sorption to that by the oxides (Lawrinenko and Laird, 2015). Even with a net negative surface charge, biochar may still have the potential to sorb $\mathrm{P}$ by other mechanisms that are not fully understood (Lehmann, 2007). It is also possible that some of the dissolved $\mathrm{P}$ is precipitated as phosphates of $\mathrm{Ca}$ and $\mathrm{Mg}$ (Novak et al., 2009). Although the levels of Ca (200 mg $\left.\mathrm{kg}^{-1}\right)$ and $\mathrm{Mg}\left(20 \mathrm{mg} \mathrm{kg}^{-1}\right)$ in the biochar tested were probably low to make a significant impact on the solution concentrations of these elements (Atkinson et al., 2010).

Phosphorus sorption increased as temperature increased from $15{ }^{\circ} \mathrm{C}$ to $25{ }^{\circ} \mathrm{C}$ and the increase in sorption was statistically significant for the no biochar control treatment, indicating an acceleration in sorption with the increase in temperature. However, $\mathrm{P}$ sorption decreased when temperature increased from $25^{\circ} \mathrm{C}$ to $35^{\circ} \mathrm{C}$ in treatments with and without biochar (Fig 4). A similar temperature effect on P sorption was observed by Sheppard and Racz (1984), who reported a decrease in the amount of applied $\mathrm{P}$ extracted with an increase in incubation temperature from $10{ }^{\circ} \mathrm{C}$ to $25^{\circ} \mathrm{C}$, indicating an increase in sorption with the increase in temperature. A further increase in the incubation temperature in their study increased the $\mathrm{P}$ extractability, hence reduced the sorption, indicating endothermic desorption reactions. Similarly, Barrow and Shaw (1975) reported P desorption to be an endothermic reaction.

The kinetic data from this study provide some insights into the effect of temperature on $\mathrm{P}$ adsorption and indicate that biochar application can increase $\mathrm{P}$ sorption in soils containing $\mathrm{Fe}$ 
and $\mathrm{Al}$ oxides. However, importantly, the low activation energies measured indicate that $\mathrm{P}$ is not strongly sorbed and may still be available to plants. Further studies with soils and various biochars are needed before field level $\mathrm{P}$ and biochar management strategies can be devised.

\section{Conclusion}

Overall, biochar application enhanced cumulative $\mathrm{P}$ sorption by both oxides, and the increase in sorption was greater for Al-goethite. Increased P sorption may minimize the off-site migration of bioavailable forms of $\mathrm{P}$. Averaged across oxides, biochar application increased cumulative $\mathrm{P}$ sorption at the lowest temperature tested $\left(15^{\circ} \mathrm{C}\right)$ but not at higher temperatures. Regardless of biochar rate, cumulative $\mathrm{P}$ sorption decreased significantly at $35^{\circ} \mathrm{C}$ relative to the two lower temperatures. Phosphorus sorption by biochar-amended oxides was associated with a low activation energy $\left(E_{a}\right)$, indicating that the sorbed $\mathrm{P}$ in soils containing goethite and Al-goethite could still become available to plants.

\section{Acknowledgements}

This project was funded in part by the University of Manitoba. The authors thank Yeukai Katanda, Rob Ellis, and Neil Ball for technical assistance, and Tee Bon Goh for his insightful comments during the preparation of the manuscript. We thank the Microscopy and Ultrastructural Analysis Laboratory, Department of Plant Pathology, Federal University of Lavras, Brazil, for assistance with SEM and X-ray microanalysis. 


\section{REFERENCES}

Ainsworth, C.C. and Sumner, M.E. 1985. Effect of aluminum substitution in goethite in on phosphorus sorption: II. Rate of sorption: Soil Sci. Soc. Amer. J. 49:1149-1153.

Antelo, J., Avena, M., Fiol, S., Lopez, R., and Arce, F. 2005. Effects of pH and ionic strength on the sorption of phosphate and arsenate at the goethite-water interface. J. Colloid Interface Sci. 285:476-486.

Atkinson, C.J., Fitsgerald, J.D., and Hipps, N.A. 2010. Potential mechanisms for achieving agricultural benefits from biochar application to temperate soils: a review. Plant Soil. 337:118.

Barrow, N.J. 1979. Three effects of temperature on the reactions between inorganic phosphate and soil. J. Soil Sci. 30: 271-279.

Barrow, N.J. 1983. A mechanistic model for describing the sorption and desorption of phosphate by soil. J. Soil Sci. 34:733-750.

Barrow, N.J. 1984. Modeling the effects of $\mathrm{pH}$ on phosphate sorption by soils. J. Soil Sci. 35:283-297.

Barrow, N.J. and Shaw, T.C., 1975. The slow reactions between soil and anions: 2. Effect of time and temperature on the decrease in phosphate concentration in the soil solution. Soil Sci. 119:167-177.

Chien, S.H., Savant, N.K., and Mokwunye, U. 1982. Effect of temperature on phosphate sorption and desorption in two acid soils. Soil Sci. 133: 160-166.

Cordell, D., Drangert, J., and White, S. 2009. The story of phosphorus: Global food security and food for thought. Glob. Environ. Change 19:292-305.

Cordell, D., Rosemarin, A.J., Schroder, J., and Smit, A.L. 2011. Towards global phosphorus security: A systems framework for phosphorus recovery and reuse options. Chemosphere $84: 747-758$.

Cornell, R.M., and Schwertmann, U. 2003. The iron oxides: structure, properties, reactions, occurrences, and uses. John Wiley and Sons, New York.

Cui, H., Wang, M.K., Fu, M., and Ci, E. 2011. Enhancing phosphorus availability in phosphorusfertilized zones by reducing phosphate adsorbed on ferrihydrite using rice straw-derived biochar. J. Soils Sediments 11:1135-1141. 
Daza-Torres, M.C., Ãlvarez-Herrera, J.G., and Camacho-Tamayo, J.H. 2008. Application of organic and inorganic materials and phosphorus adsorption in an Oxisol. Rev. Bras. Eng. Agríc. Ambient. 12:451-457.

Dedavid, B.A., Gomes, C.I., and Machado, G. 2007. Microscopia eletrônica de varredura: aplicações e preparação de amostras. Edipucrs, Porto Alegre, RS.

Duku, M.H., Gu, S., and Ben Hagan, E. 2011. Biochar production potential in Ghana-a review. Renew. Sustainable Energy Rev. 15:3539-3551.Fu, Z., F. Wu, K. Song, Y. Lin, Y. Bai, Y. Zhu, and J.P. Giesy. 2013. Competitive interaction between soil-derived humic acid and phosphate on goethite. Appl. Geochem. 36:125-131.

Gardner, B.R., and Jones, J.P. 1973. Effects of temperature on phosphate sorption isotherms and phosphate desorption. Commun. Soil Sci. Plant Anal. 4: 83-93.

Hua, M., Zhang, S., Pan, B., Zhang, W., Lv, L., and Zhang, Q. 2012. Heavy metal removal from water/wastewater by nanosized metal oxides: A review. J. Hazard. Mater. 211:317-331.

Iqbal, H., Garcia-Perez, M., and Flury, M. 2015. Effect of biochar on leaching of organic carbon, nitrogen, and phosphorus from compost in bioretention systems. Sci. Total Environ. 521:3745.

Jaisi, D.P., Blake, R.E., and Kukkadapu, R.K. 2010. Fractionation of oxygen isotopes in phosphate during its interactions with iron oxides. Geochim. Cosmochim. Acta 74:13091319.

Jiang, J., Yuan, M., Xu, R., and Bish, D.L. 2015. Mobilization of phosphate in variable-charge soils amended with biochars derived from crop straws. Soil Tillage Res. 146:139-147.

Kookana, R.S., Sarmah, A.K., Van Zwieten, L., Krull, E., and Singh, B. 2011. Biochar application to soil: Agronomic and environmental benefits and unintended consequences. Adv. Agron. 112:103-143.

Kuo, S., and Lotse, E.G. 1973. Kinetics of phosphate adsorption by hematite and gibbsite. Soil Sci. 116:400-406.

Lawrinenko, M., and Laird, D.A. 2015. Anion exchange capacity of biochar. Green Chem. 17:4628-4636.

Lehmann, J. 2007. Bio-energy in the black. Frontiers in Ecology and the Environment 5:381387.

Lehmann, J., da Silva, J.P., Steiner, C., Nehls, T., Zech, W., and Glaser, B. 2003. Nutrient availability and leaching in an archaeological anthrosol and a ferralsol of the central amazon basin: Fertilizer, manure and charcoal amendments. Plant Soil 249:343-357. 
Liang, B., Lehmann, J., Solomon, D., Kinyangi, J., Grossman, J., O'Neill, B., Skjemstad, J.O., Thies, J., Luizao, F.J., Petersen, J., and Neves, E.G. 2006. Black carbon increases cation exchange capacity in soils. Soil Sci. Soc. Am. J. 70:1719-1730.

Liu, C., and Huang, P.M. 2000. Kinetics of phosphate adsorption on iron oxides formed under the influence of citrate. Can. J. Soil Sci. 80:445-454.

Luengo, C., Brigante, M., and Avena, M. 2007. Sorption kinetics of phosphate and arsenate on goethite. A comparative study. J. Colloid Interface Sci. 311:354-360.

Manitoba Soil Fertility Guide. 2007. [Online]. Available: https://www.gov.mb.ca/agriculture/crops/soil-fertility/soil-fertilityguide/pubs/soil_fertility_guide.pdf [10 Oct. 2017]

Martin, R.R., Tazaki, K., and Smart, R.S.C. 1988. Direct observation of phosphate precipitation in the goethite/ phosphate system. Soil Sci. Soc. Am. J. 52:1492-1500.

Mezenner, N.Y. and Bensmaili, A. 2009. Kinetics and thermodynamic study of phosphate adsorption on iron hydroxide-eggshell waste. Chem. Eng. J. 147: 87-96.

Novak, J.M., Busscher, W.J., Laird, D.L., Ahmedna, M., Watts, D.W., and Niandou, M.A.S. 2009. Impact of biochar amendment on fertility of a southeastern coastal plain soil. Soil Sci. 174:105-112.

Parvage, M.M., Ulen, B., Eriksson, J., Strock, J., and Kirchmann, H. 2013. Phosphorus availability in soils amended with wheat residue char. Biol. Fertility Soils 49:245-250.

Persson, P., Andersson, T., Nelson, H., Sjoberg, S., Giesler, R., and Lovgren, L. 2012. Surface complexes of monomethyl phosphate stabilized by hydrogen bonding on goethite (alphaFeOOH) nanoparticles. J. Colloid Interface Sci. 386:350-358.

Qafoku, N., Van Ranst, E., Noble, A., and Baert, G. 2004. Variable charge soils: Their mineralogy, chemistry, and management. Adv. Agron. 84:159-215.

Ruan, H.D., and Gilkes, R.J. 1996. Kinetics of phosphate sorption and desorption by synthetic aluminous goethite before and after thermal transformation to hematite. Clay Miner. 31:6374.

SAS Institute. 2013. SAS/STAT User's guide. Version 9.4. SAS Institute Inc., Cary, N.C. USA

Sheppard, S.C., and Racz, G.J. 1984. Effects of soil temperature on phosphorus extractability. I. Extractions and plant uptake of soil and fertilizer phosphorus. Can. J. Soil Sci. 64: 241-254.

Schoumans, O.F., Bouraoui, F., Kabbe, C., Oenema, O., and van Dijk, K.C. 2015. Phosphorus management in Europe in a changing world. Ambio 44:S180-S192. 
Schulze, D.G. 1984. The influence of aluminum on iron oxides. VIII. Unit-cell dimensions of A1substituted goethites and estimation of Al from them. Clay Miner. 32:36-44.

Schulze, D.G., and Schwertmann, U. 1984. The influence of aluminum on iron oxides: X. properties of Al-substituted goethites. Clay Miner. 19:521-539.

Sibanda, H.M., and Young, S.D. 1986. Competitive sorption of humus acids and phosphate on goethite, gibbsite, and 2 tropical soils. J. Soil Sci. 37:197-204.

Soinne, H., Hovi, J., Tammeorg, P., and Turtola, E. 2014. Effect of biochar on phosphorus sorption and clay soil aggregate stability. Geoderma 219-220:162-167.

Sparks, D.L. 1989. Kinetics of soil chemical processes. In: Sparks editors, Application of chemical kinetics to soil chemical reactions. Academic Press Inc, California. p. 4-38.

Spokas, K.A., Novak, J.M., and Venterea, R.T. 2012. Biochar's role as an alternative N-fertilizer: Ammonia capture. Plant Soil 350:35-42.

Strauss, S., Brummer, G.W., and Barrow, N.J. 1997. Effects of crystallinity of goethite: II. Rate of sorption and desorption of phosphate. Eur. J. Soil Sci. 48:101-114.

Torrent, J., Schwertmann, U., and Barron, V. 1992. Fast and slow phosphate sorption by goethite-rich natural materials. Clays Clay Miner. 40:14-21.

Wambeke, A. 1992. Soils of the tropics: properties and appraisal. McGraw-Hill, New York.

Weber, W.J., McGinley, P.M., and Katz, L.E. 1991. Sorption phenomena in subsurface systems: concepts, models, and effects on contaminant fate and transport. Water Res. 25:499-528.

Weng, L., Van Riemsdijk, W.H., and Hiemstra, T. 2012. Factors controlling phosphate interaction with iron oxides. J. Environ. Qual. 41:628-635.

Xu, G., Sun, J., Shao, H., and Chang, S.X. 2014. Biochar had effects on phosphorus sorption and desorption in three soils with differing acidity. Ecol. Eng. 62:54-60.

Yao, F.X., Arbestain, M.C., Virgel, S., Blanco, F., Arostegui, J., Macia-Agullo, J.A., and Macias, F. 2010. Simulated geochemical weathering of a mineral ash-rich biochar in a modified soxhlet reactor. Chemosphere 80:724-732.

Zhao, L., Cao, X., Wang, Q., Yang, F., and Xu, S. 2013. Mineral constituents profile of biochar derived from diversified waste biomasses: Implications for agricultural applications. J. Environ. Qual. 42: 545-552.

Zhao, S., Wang, B., Gao, Q., Gao, Y., and Liu, S. 2017. Adsorption of phosphorus by different biochars. Spectrosc. Lett. 50: 73-80. 
Table 1. Selected chemical properties of the biochar.

\begin{tabular}{|c|c|c|c|c|c|c|c|c|c|}
\hline $\mathrm{Ca} \uparrow$ & $\mathrm{Mg}$ & $\mathrm{K}$ & $\mathrm{Na}$ & CEC & $\mathrm{pH}$ & $\mathrm{Nt}$ & $\mathrm{C}$ & $\mathrm{P}$ & $\mathrm{S}$ \\
\hline 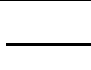 & $-\mathrm{mg}$ & & - & \multirow{2}{*}{$\begin{array}{c}\mathrm{cmol}_{\mathrm{c}} \mathrm{kg}^{-} \\
1.8\end{array}$} & \multirow[b]{2}{*}{8.6} & $-\mathrm{g}$ & & \multicolumn{2}{|c|}{$-\mathrm{mg} \mathrm{kg}^{-1}-$} \\
\hline 200 & 20 & 96 & 81 & & & 0.27 & 427 & 61 & 28 \\
\hline
\end{tabular}

$\dagger$ Exchangeable cation concentrations in biochar; $\ddagger$ total C, N, P and S concentrations in biochar 
Table 2. Results of X-ray microanalysis of goethite and aluminum substituted goethite (Algoethite).

\begin{tabular}{lcc}
\hline Element & Goethite & Al-goethite \\
\cline { 2 - 3 } & & $\%$ \\
Iron & 71.8 & 73.5 \\
Oxygen & 26.9 & 23.5 \\
Aluminum & 0.69 & 2.96 \\
Potassium & 0.53 & - \\
\hline
\end{tabular}


Table 3. Least square mean cumulative phosphorus sorption as affected by biochar, oxide, and temperature after $24 \mathrm{~h}$ of reaction

\begin{tabular}{lc}
\hline Treatment & $\begin{array}{c}\text { Cumulative P } \\
\text { Sorption }\end{array}$ \\
\hline Biochar & $\mathrm{mg} \mathrm{g}^{-1}$ \\
0 & $1.87(0.08) \dagger$ \\
$40 \mathrm{~g} \mathrm{~kg}^{-1}$ & $2.26(0.08)$ \\
Oxide & \\
Goethite & $1.87(0.09)$ \\
Al-goethite & $2.27(0.09)$ \\
& \\
Temperature & \\
$15 \mathrm{C}$ & $2.19(0.13)$ \\
$25 \mathrm{C}$ & $2.83(0.13)$ \\
$35 \mathrm{C}$ & $1.18(0.13)$ \\
& $\mathrm{P}$ value \\
Biochar & $<0.001$ \\
Oxide & 0.01 \\
Temperature & 0.0003 \\
Biochar $\times$ Oxide & 0.02 \\
Biochar $\times$ Temperature & $<0.001$ \\
Biochar $\times$ Oxide $\times$ Temperature & 0.39 \\
\hline
\end{tabular}

$\dagger$ Mean separation letters are not applied because the interactions are significant. The significant interactions are plotted in Fig. 3 and Fig. 4. Values in parenthesis are the standard error of mean. 


\section{Figure Captions}

Fig. 1. Results of XRD analysis for Al-goethite (A) and goethite (B).

Fig. 2. Pseudo-first-order sorption kinetics of phosphorus by goethite and Al-goethite as affected by biochar application and temperature. Rate constants $\left(k, \mathrm{~h}^{-1}\right)$ are presented for each temperature in the legend. RMSE, root mean square error.

Fig. 3. Differences in the amount of sorbed $\mathrm{P}$ after $24 \mathrm{~h}$ of reaction time for goethite and Alsubstituted goethite, with and without biochar, averaged across temperature.

Fig. 4. Differences in the amount of sorbed $\mathrm{P}$ after $24 \mathrm{~h}$ of reaction time at $15^{\circ} \mathrm{C}, 25^{\circ} \mathrm{C}$, and $35^{\circ} \mathrm{C}$, with and without biochar. 


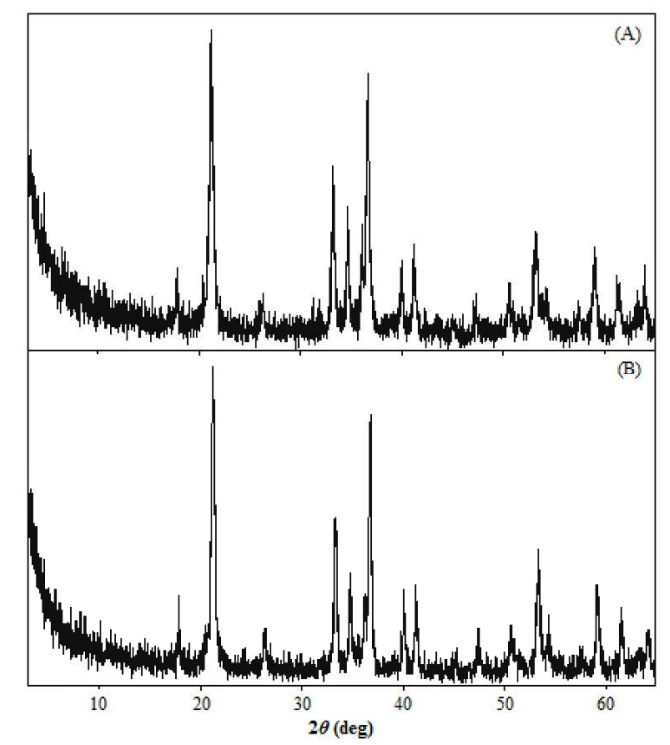

1

$279 \times 361 \mathrm{~mm}(300 \times 300 \mathrm{DPI})$

https://mc.manuscriptcentral.com/cjss-pubs 

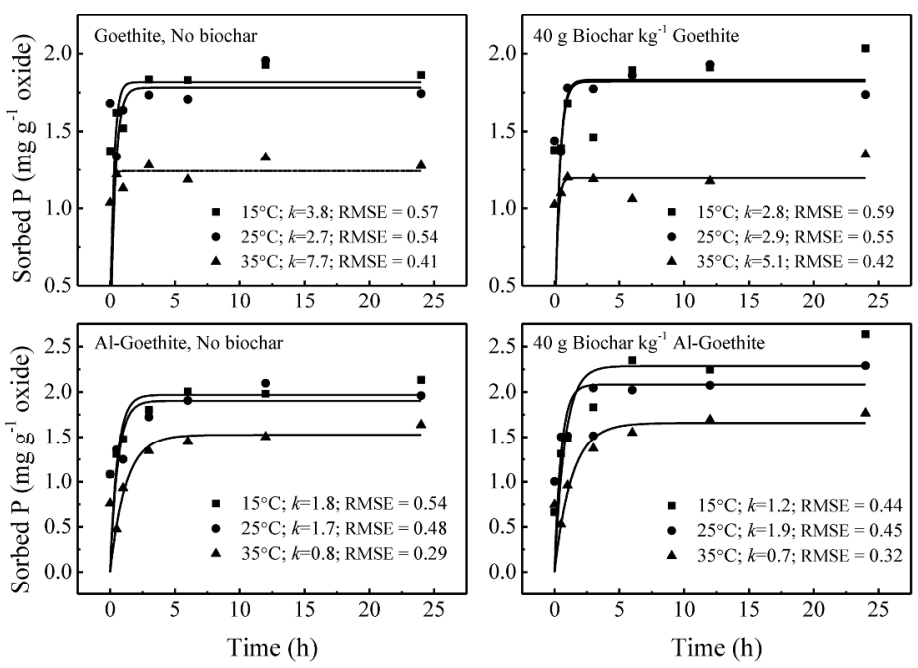

$279 \times 361 \mathrm{~mm}(300 \times 300$ DPI $)$ 


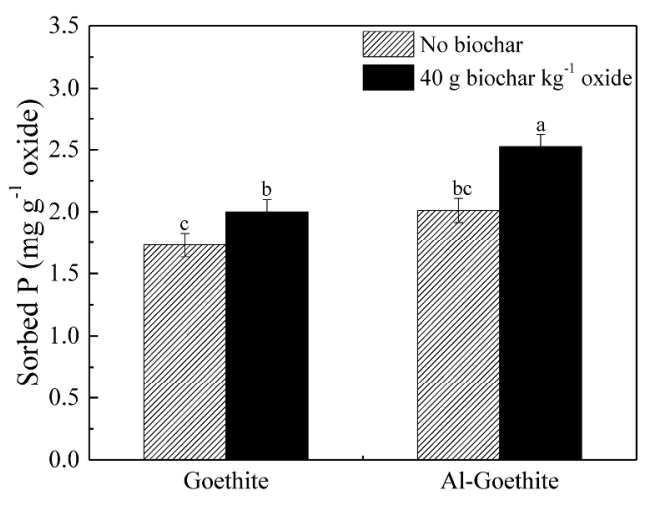

$279 \times 361 \mathrm{~mm}(300 \times 300$ DPI $)$

https://mc.manuscriptcentral.com/cjss-pubs 


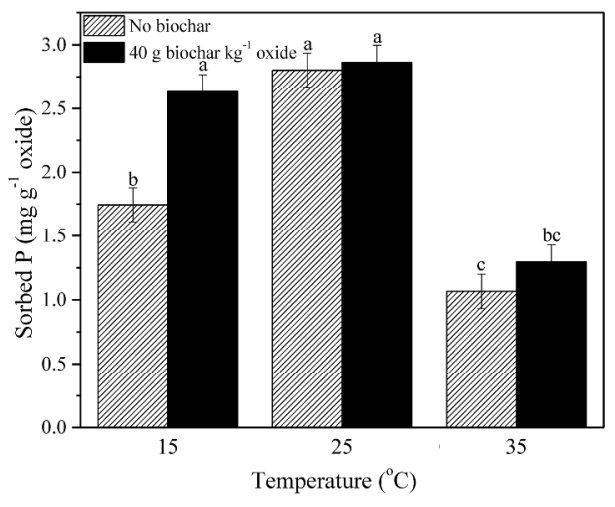

4

$279 \times 361 \mathrm{~mm}(300 \times 300 \mathrm{DPI})$

https://mc.manuscriptcentral.com/cjss-pubs 